\title{
Editorial
}

\section{Publisher's Note: Continued Publication of Gastroenterology Insights by MDPI}

\author{
Franck Vazquez \\ MDPI, St. Alban-Anlage 66, CH-4052 Basel, Switzerland; Vazquez@mdpi.com
}

Received: 27 July 2020; Accepted: 30 July 2020; Published: 15 August 2020

Gastroenterology Insights was launched in 2009 and it has been published over the past eleven years by PAGEPress Publications, with a total of 88 papers released [1]. Dr. Joseph D. Feuerstein from Harvard Medical School has served as the Editor-in-Chief since 2015 and is still currently active in this role. To ensure that we serve all academic communities well, MDPI took over the publication of Gastroenterology Insights from PAGEPress and continues to publish the journal since 20 July 2020. We will publish two quarterly issues in 2020, and regularly publish four quarterly issues starting from 2021.

Gastroenterology Insights has a great potential to be an influential journal and to serve its scientific communities. We are committed to making the journal a success, by involving more established researchers in the Editorial Board, launching interesting Special Issues, publishing high-quality papers, and getting the journal included in major indexing and abstracting services.

We look forward to publishing your work in Gastroenterology Insights.

\section{Reference}

1. Gastroenterology Insights Homepage. Available online: https://www.pagepress.org/journals/index.php/gi/ index (accessed on 27 July 2020).

(C) 2020 by the author. Licensee MDPI, Basel, Switzerland. This article is an open access article distributed under the terms and conditions of the Creative Commons Attribution (CC BY) license (http://creativecommons.org/licenses/by/4.0/). 